\title{
Linguistic and visual strategies for portraying immigrants as people deprived of human rights ${ }^{\dagger}$
}

\author{
María Martínez Lirola ${ }^{\mathrm{a}, \mathrm{b}}$ \\ ${ }^{\text {a} D e p a r t a m e n t o ~ d e ~ F i l o l o g i ́ a ~ I n g l e s a, ~ U n i v e r s i d a d ~ d e ~ A l i c a n t e, ~ A l i c a n t e, ~ S p a i n ; ~}{ }^{b}$ Department of Linguistics and \\ Modern Languages, University of South Africa, Pretoria, South Africa
}

\section{ABSTRACT}

The majority of news items on sub-Saharan immigrants in the Spanish press refer to their arrival by jumping the fences of Ceuta or Melilla or landing in small boats at the Spanish coast. The data in this article consist of all the news items published on the arrival of sub-Saharan immigrants in Spain by jumping the fences of Ceuta and Melilla, items that appeared in the digital editions of the two most popular Spanish newspapers, El País and $A B C$, from 1 January 2012 to 1 January 2015. The principles of critical discourse analysis and visual grammar are used to deconstruct the linguistic and visual portrayal of sub-Saharan immigrants when they try to enter Spain by jumping the fence. This research reveals that the immigrants jumping the fence at Melilla are represented as wild and dangerous. There is no reference to their human rights. The study thus aims to provide a visual analysis of the way in which the arrival of these immigrants is represented visually in two serious newspapers. In this way, the study aims to unveil visual ways of negative representation of immigrants, who are portrayed as dangerous invaders.

\section{KEYWORDS}

Sub-Saharan immigrants; critical discourse analysis; visual grammar; human rights; press

\section{Introduction: exploring the relationships between immigration and media discourse}

Spain has been receiving immigrants of various nationalities in the last few decades; they arrive with the purpose of finding a job and improving their social-economic situation. Although it might seem that the economic crisis that Spain has been suffering in the past few years has stopped immigrants from coming, because there were fewer jobs (Bañón and Romero 2013; Martínez Lirola 2013), news items in the Spanish press indicate that immigrants continue to arrive. For example, in 2012-14 there were many occasions when sub-Saharans tried to enter Spain by jumping the fences in Ceuta and Melilla. In some cases they were successful.

Media have an important role in the social construction of reality in modern society. In this sense, the media in general and the press in particular have a crucial role because they inform us of the arrival of immigrants in times of crisis. Media discourse influences public

\footnotetext{
${ }^{\dagger}$ By sub-Saharan immigrants we mean those from African countries situated south of the Sahara. Therefore, the term does not include those arriving from Egypt and the Maghreb: Morocco, Tunisia, Algeria, Libya and Mauritania. It also excludes Western Sahara.

CONTACT María Martínez Lirola maria.lirola@ua.es; mlirola@hotmail.com
} 
opinion and the mental models of people by portraying others, including immigrants, in different ways. In other words, the media belong to an elite, and therefore they have power to influence readers' ideology depending on the way different social realities are described. They can choose the way they broadcast the topics connected with immigration, because readers and viewers do not always have first-hand experience (Bañón and Fornielles 2008; van Dijk 2006).

Media discourse, and that of the press in particular, has discursive elements that reproduce the superiority of white elites over less favoured social groups (Crespo and Martínez Lirola 2012; van Dijk 2006, 2008, 2011). In other words, press discourse reproduces the social inequalities that point out that the main group of the population has power over minorities. This representation justifies the necessity of studies like this one, whose main purpose is to study a specific aspect of immigrants.

We are interested in the portrayal of sub-Saharan immigrants in the Spanish press because, in general, news items dealing with these immigrants concentrate on the moment they arrive, when they jump the fences or turn up in small boats. The arrival of immigrants is perceived as a threat to the Spanish population instead of as an opportunity to promote exchange between people from different cultures and peaceful cohabitation between people from various races, religions, nationalities, beliefs, etc. (Crespo and Martínez Lirola 2012; Martínez Lirola 2014).

We intend to observe patterns of social inequality and power relations between the immigrants represented and the Spanish population. Analysing the linguistic and visual representation over three years of the sub-Saharans who arrive in Spain by jumping the fence at Melilla will provide answers to the following research questions: how are subSaharan immigrants portrayed linguistically and visually in the news items about their arrival in Melilla? Are there references to human rights in the news items under analysis?

We also pay attention to the presence or absence of references to human rights in the news items and see the extent to which the press contributes to the transmission of other discourses (Bañón 2002), such as that of human rights. This article is organized into the following sections: Section 2 offers a literature review. The main objectives, data and methodology appear in Section 3. The analysis followed by the discussion and conclusions are in Sections 5 and 6.

\section{Literature review}

As stated in Section 1, the press has power over readers when it chooses to transmit news in a particular way. Consequently, each image and each linguistic component is not chosen at random but with a communicative purpose, which influences the audience. Therefore, press discourse represents domination and power between different groups of society, in this case, between the Spanish population and sub-Saharan immigrants. In this sense, critical discourse analysis (CDA) is useful because it is a critical perspective that allows the study of a text in order to observe examples of marginalization, power or dependency, among others, in order to deconstruct the relationships of power in society (van Dijk 2008).

CDA is an eclectic methodology (Fairclough, Mulderrig, and Wodak 2011; Gee 2014; Wodak 2011) that allows delving into social problems and unveiling the relationships 
between language, power and the social, political and economic reality of society. As Wodak $(2011,52)$ makes clear:

The constant unity of language and other social matters ensures that language is entwined in social power in a number of ways: language indexes power and expresses power; language is involved where there is contention over and a challenge to power.

Language is understood as social practice (Fairclough and Wodak 1997). In this sense, CDA's main purpose is to increase the critical conscience when facing the discourse of power, so that its objective is not only to describe the world but also to transform it. In Wodak and Meyer's words $(2009,10)$ :

In sum: CDA can be defined as being fundamentally interested in analysing opaque as well as transparent structural relationships of dominance, discrimination, power and controlas manifested in language. In other words, CDA aims to investigate critically social inequality as it is expressed, constituted, legitimized, and so on, by language use (or in discourse).

There are many recent studies that analyse the representation of immigrants in the press from a CDA perspective (e.g. Alonso Belmonte, McCabe, and Chornet-Roses 2010; Bañón and Romero 2013; Checa y Olmos 2008; Lario Bastida 2006; Markovitz 2011; Martínez Lirola 2006, 2008, 2010, 2014; Moore, Gross, and Threadgold 2012; Newton 2008; Ureta 2011). For example, KhosraviNik (2010) concentrates on the portrayal of refugees, asylum seekers and immigrants in the British press. Richardson and Wodak (2013) compare recent election materials produced by Austrian and British right-wing parties with explicit xenophobic agendas, in order to observe the main strategies used to create fear of immigrants. International studies point out that immigrants are portrayed as inferior and as a threat to the main population. In addition, the general tendency is to represent immigrants as poor and uneducated (Dauvergne 2008; Newton 2008; Pham 2014; Spener 2009), suggesting they are victims (Collins 2007).

The arrival of sub-Saharan immigrants increased at the beginning of the twenty-first century, due to the difficult socio-economic situation of their countries. This economic situation was often caused by corruption in many African governments and by misuse of natural resources and power (Arango 2002; Rodríguez Breijo 2010). Most sub-Saharan immigrants arrive in Spain in one of two ways: on small boats crossing the Straits of Gibraltar or by jumping the fences that separate Ceuta and Melilla from Morocco. This article concentrates on analysing news items about the latter route.

Studies on the representation of sub-Saharan immigrants in the press point out that they are represented as victims who need help and support from the Spanish population. Many immigrants need health care and social resources, among other things, when they arrive in Spain (Hatoss 2012; Kiwan 2009; Riccio 2001; Triandafyllidou and Maroukis 2012). Consequently, connecting immigrants with social problems and even with crime portrays them as people who cause problems and whose presence is seen as a burden for the country of arrival. In addition, few studies look at the representation of immigrants jumping the fence at Melilla (Concepción Sepúlveda, Alsina, and Bravo 2008; Rodríguez Breijo 2010). These studies concentrate on the linguistic representation of immigrants in only one newspaper or on their representation on television. Thus, this study is important because it pays attention not only to the linguistic but also to the visual representation of immigrants in the process of jumping the fence. Moreover, the data have been recently 
obtained from more than one newspaper, which allows the observation of certain patterns in immigrants' representation in the press.

\subsection{Immigration and human rights}

The following paragraphs refer to some crucial aspects of human rights because the analysis pays attention to the references, or lack of references to immigrants' human rights in the texts under analysis (Human Rights Declaration 1948). This study emphasizes the necessity of avoiding discrimination against immigrants, treating them equally and respecting their human rights. This is the reason that we chose a framework based on human rights in order to promote social justice. As Gready and Vanhenhole $(2014,12)$ state:

A human rights framing is attractive to social justice advocates because it speaks of entitlement, not charity; provides a language in which transnational discussions can take place; and brings to bear an international legal framework with claims to universal acceptance that outstrip other normative frameworks.

On December 10, 1948, the General Assembly of the United Nations proclaimed the Universal Declaration of Human Rights (UDHR). Among these rights is the right to life, freedom of expression, the prohibition of torture and discrimination. The UDHR is important because it points out the necessity of respecting the dignity of each human being. As Article 1 states: All human beings are born free and equal in dignity and rights. They are endowed with reason and conscience and should act towards one another in a spirit of brotherhood". In this sense, the UDHR is one of the main creations in the history of humanity for the ideals of coexistence that it proposes (Mestre Chust 2007, 13).

Human rights must be present in the places where there are conflicts among the civil population (Goodhart 2009; Marchetti and Tocci 2011). Their application all over the planet must continue to be one of the most important vindications in the twenty-first century (Goodhart and Mihr 2011; Steiner, Alston, and Goodman 2007) because human rights go with the development of a culture of peace (Goh, Offord, and Garbutt 2012). Moreover, human rights must be understood as a series of principles that promote justice and peaceful coexistence among human beings regardless of racial, religious or other differences. As Osler and Starkey $(2010,43)$ make clear:

The Universal Declaration of Human Rights (UDHR) presents a vision of a peaceful world; the outcome of a struggle by humanity to implement justice. It offers an emancipatory manifesto, a set of shared principles for living together and an agenda for action developed in response to the repressive totalitarian ideologies of the mid-twentieth century. The realisation of this vision of justice and peace is a utopian project.

Different national and international studies concentrate on exploring the way in which immigrants are presented as illegal, highlighting the negative aspects of immigration by recurring references to their illegal entry, their use of social resources and their difficulties in adapting (Bacon 2008; Collins 2007; Hanson 2009; Kaced 2011; Mullor 2011; Newton 2008; Sobrados León 2011); that is, the majority of studies see immigration as a problem and connect immigrants with conflict and crime.

Moreover, several studies concentrate on the relationships between human rights and immigration (Estévez 2012; Gavison 2010; Thym 2008). These studies emphasize that there are few references to immigrants in the discourse of human rights. Therefore, it is 
necessary to make evident the fact that many immigrants are deprived of basic rights. As Estévez $(2012,106)$ makes clear:

Ethnic minorities become so because they are socially marginalised - that is, they are denied citizenship or the enjoyment of rights since they are members of former colonies or ultimately because they are the victims of a more generalised rejection of cultural diversity. The social marginalization of immigrants can be seen when they are concentrated in marginalized residential areas, perform work with a low social status, and find their access to services and rights is limited due to their being a foreigner or noncitizen.

In this sense, it is necessary to reclaim not only human rights as a historical conquest but also their presence in the discourse of elites. This would contribute to the creation of a discourse and to a social awareness that can transform reality so that human rights develop from being a theoretical conquest to a reality that can benefit all human beings, following Gavison (2010, 9):

[... ] the related distinction between the basic recognition of a universal human right, and the processes of identifying the nature and scope of the duties such recognition involves, the identity of those subject to the duties, and the nature of the mechanisms available - if at all - to enforce these duties. While human rights recognized in international documents are meant to be universal, the task of authoritatively deciding on their scope, and especially the task of in fact promoting them, is relegated to the states and international organizations, which often interpret the rights and their implications in different ways.

The majority of studies that approach immigration from a human rights perspective are in sociology and law (e.g. Dembour and Kelly 2011; Risse, Ropp, and Sikkink 2013; RubioMarín 2014). This study aims to offer a critical discourse analysis of the corpus and observe the presence or absence of human rights in the written texts and in the visuals of the texts under analysis. Therefore, this paper will contribute to the discursive representation of immigrants.

\section{Objectives, data and methodology}

210 This study intends to contribute to the representation of the arrival of sub-Saharan immigrants in the Spanish press, as a way to foreground their situation and to observe the way they are represented in a sample from the Spanish press. In addition, we intend to observe if there are references to the respect or violation of immigrants' human rights in the news items under study.

In order to prepare the corpus, we compiled all the news items on immigration published in the digital editions of the Spanish newspapers $A B C$ and El País ( $A B C$ 20122015; El País 2012-2015) from Monday to Friday. These two newspapers were selected because they are two of the main Spanish newspapers, they have the highest readership and the highest online viewership (Martínez Lirola 2013). Moreover, they were chosen because their ideology is different: $E I$ País is regarded as left-wing, whereas $A B C$ is regarded as right-wing. The data for this paper consist of all the news reports published between 1 January 2012 and 1 January 2015 on the arrival of sub-Saharan immigrants in Spain. Specifically, these immigrants arrived by jumping the fence in Melilla. These three years were selected because they coincide with three years of the Spanish financial crisis.

Following the tradition of CDA, our approach is mainly qualitative. However, it is also necessary to mention the general quantitative characteristics of the corpus. All news 
items on sub-Saharan immigrants to Spain were collected. Then, we decided to concentrate on those that concern the arrival of immigrants who jump the fence in Ceuta and Melilla. The total number of news reports collected during this period is 132 . Of these, 79 are from $A B C$ and 53 are from El País. Most of the texts are multimodal (79), but some are monomodal (53).

After revising and analysing all of the texts, we chose some examples that show the main linguistic and visual characteristics found in the corpus (see Section 4). The total number of texts is very large for qualitative textual analysis, and it is not possible to offer a close analysis of every news item within the scope of one article. Therefore, the texts selected are representative of the main linguistic and visual aspects presented in the news reports.

The principles of CDA are used in order to deconstruct power relations and to deepen the representation of sub-Saharan immigrants in a sample from the Spanish press. We can thus observe patterns of discrimination and the relationships between discourse and society. The main types of composition in multimodal texts are also taken into consideration, following the model of visual grammar proposed by Kress and van Leeuwen (2006): information value, salience and framing. In addition, Van Leeuwen's (2008) characterization of social actors is used in order to study how sub-Saharan immigrants are portrayed and to observe social distance, social relation and social interaction, in order to understand how immigrants are depicted in the photographs and to observe how interpersonal relations with the audience are established (Van Leeuwen 2008, 138). These various approaches are very useful in analysing the way in which discourse reproduces social domination.

\section{Results}

As mentioned, our corpus was compiled over three years. However, due to the limitations of this paper and in order to offer some recent data, the texts selected and analysed in detail in this section are from 2014. It is significant that, of the 132 news items compiled in three years, 86 were published in 2014. They have also been selected because they are representative of the main way sub-Saharan immigrants who jump the fence at Melilla are portrayed. The study of the written and visual language in this section allows us to observe the main strategies used to create the Other, in this case, the sub-Saharan, as a person who threatens the established order and who can be dangerous for the security of the country.

\subsection{General analysis of the language and the images}

The four texts under analysis have been selected because they have some characteristics that contribute to representing immigrants in a negative way, supported by the language used in the news items. Due to space restrictions in this paper, we concentrate on the language used in the headings and the captions. There are examples of appraisement (Van Leeuwen 2008, 45) in the written language of the news item. In the author's words: "social actors are appraised when they are referred to in terms which evaluate them as good or bad, loved or hated, admired or pitied".

One of the main linguistic characteristics of the headings and captions analysed is that, linguistically, sub-Saharan immigrants are named using "collectivization", because they are referred to with nouns denoting a group of people (mainly immigrants, sub-Saharans or 
sub-Saharan immigrants; they are called los encaramados (the climbers) or inmigrantes encaramados (climbing immigrants; see text 1).

They are not referred to in a very negative way, but the action they take is that of jumping, which implies that they have entered the country in an unexpected way and therefore threaten the Spanish population. The use of figures in the news items and the use of terms such as avalanches or massive arrivals contribute to the creation of fear in the readers. Moreover, the use of the noun encaramados (climbers) suggests that they are able to climb and jump because they are willing to risk their lives in order to fight for their dream of entering Spain and starting a new life in Europe. They do this so that they can help their families in their home countries.

There are no references to human rights in the language used in the texts analysed, which can be understood in two ways. The first is that it is taken for granted that immigrants' human rights are respected and taken care of. Another interpretation is that immigrants' human rights are neglected. They are deprived of them, and their invisibility in the news items under analysis suggests that this is not a priority for the government in charge of promoting the legal measures that must stop immigrants arriving in Spain. Journalists do not make reference to human rights because their main concern is to report on the immigrants arriving in large groups.

There are some photographs in the corpus that represent immigrants lying or sitting on the floor after successfully jumping the fence. Some are being accompanied by security forces to receive medical attention or to be taken to CETI (Centro de Estancia Temporal de Inmigrantes, a temporary centre for immigrants until they are deported). But the majority of the photographs are of the moment the immigrants are jumping, and that is why a sample of those photos are analysed in detail in this section.

All four photographs are medium size; they are framed, which implies that the elements in the photograph belong together. However, the frame is not very strong. In Kress and van Leeuwen's words (2006, 203): "The stronger the framing of an element, the more it is presented as a separate unit of information".

Immigrants appear along the entire photograph although there is a general tendency to represent more people on the left side, where information is provided (see texts 2 and 3). Therefore, the most salient elements in the visuals are the social actors represented although, depending on their position, some are more salient than others, as the following analysis will show.

The news items under analysis highlight the courage and perseverance of the immigrants who jump the fence because they are active in their own migratory process and accept the challenge of leaving their families and their former lives. They take the risk of jumping the fence although they know that there is a high possibility of being discovered. Portraying immigrants as illegal contributes to observing a subtle othering of them because they are presented as those who are not like the main group of society and will never be. Their representation in the photographs under analysis makes clear that their worst aspects are portrayed: they appear violent, illegal, semi-naked, fighting with security forces, etc. In this sense, following Van Leeuwen (2000, $333 \mathrm{ff}$.) and his concept of visual racism, we use the term visual dysphemism to refer to the cases in which images show the negative side of a social reality or group of people.

Immigrants can be observed, but there is no dialogue with the readers; therefore, this contributes to presenting them dysphemistially. Moreover, presenting immigrants with 
their backs to the audience, not looking at the camera or covering part of their bodies, contributes to their negative representation. Text 3 is an example. The fence covers many immigrants, so they appear blurred; moreover, choosing an oblique angle contributes to detaching the reality of immigrants from that of the viewers.

The fact that the police appear in some of the images analysed (see texts 2 and 4) contributes to the construction of immigrants as criminals. This highlights the we-they dichotomy and avoids any possibility for immigrants to have the status of citizens. This goes with the fact that people tend to remember negative information much better than they do positive information. Hence, the positive characteristics of immigrants do not normally appear in the press, as the texts under analysis make clear. It is also significant that there are no women in the news items collected.

TEXT 1

Comienzan a devolver a los inmigrantes encaramados a la valla de Melilla (They are starting to send back the immigrants that climbed the Melilla fence).

$A B C$, agenciasmelillaefe, 03-04-2014. http://www.abc.es/espana/20140403/abci-inmigrantesmelilla-201404031020.html (Figure 1).

TEXT 2

Casi 400 inmigrantes tratan de saltar la valla en Melilla (About 400 immigrants try to jump the fence in Melilla).

El intento, frustrado, se produjo a las 22 horas, tras la ruptura del ayuno del Ramadán (The attempt, which was frustrated, took place at $11 \mathrm{pm}$, after the breaking of the Ramadán fast).

El País, Agencias, 06-07-2014. http://politica.elpais.com/politica/2014/07/06/actualidad/ 1404638871_536272.html (Figure 2).

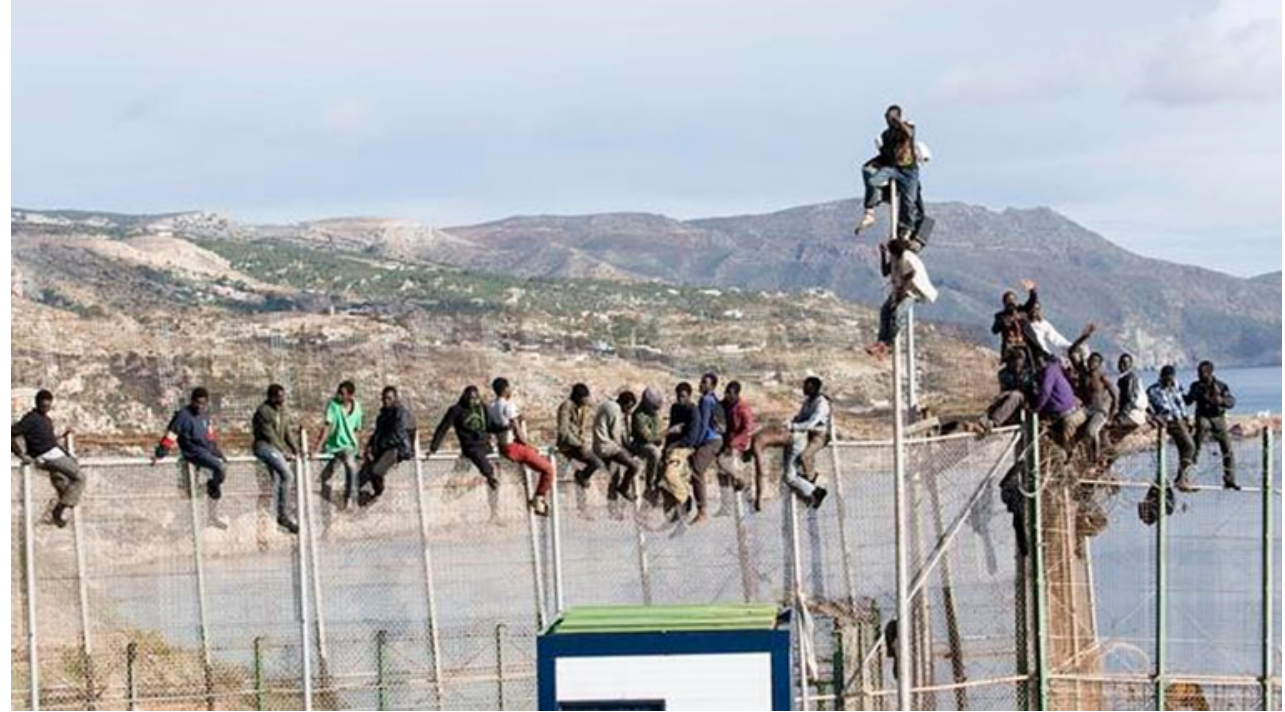

Figure 1. EFE. Unos 25 inmigrantes se subieron a la valla de Melilla (Some 25 immigrants climb the fence in Melilla). 


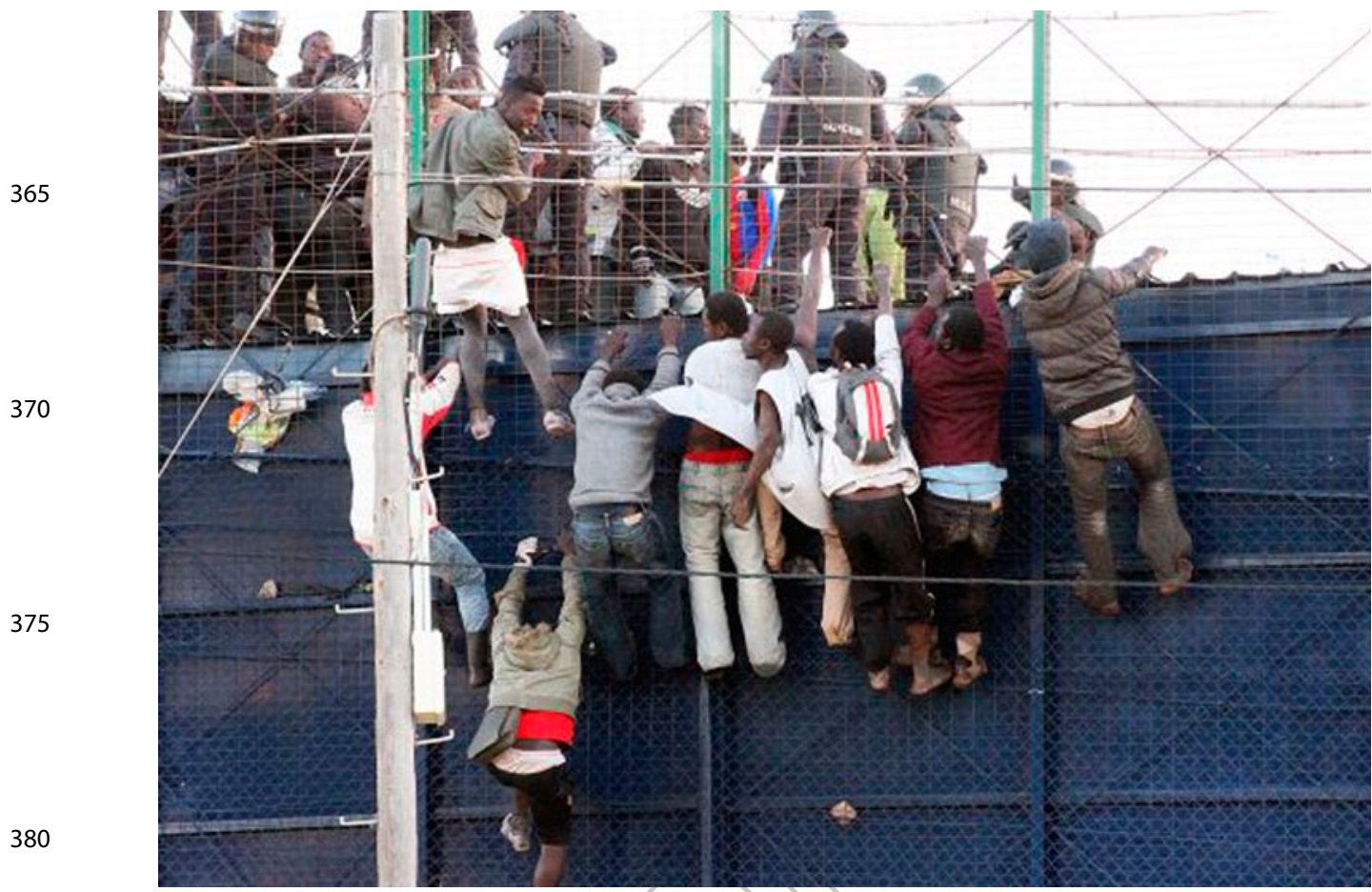

Figure 2. Varios subsaharianos tratan de saltar la valla de Melilla el pasado abril. /ANTONIO RUIZ

(Several sub-Saharans try to jump the fence in Melilla this past April/ANTONIO RUIZ).

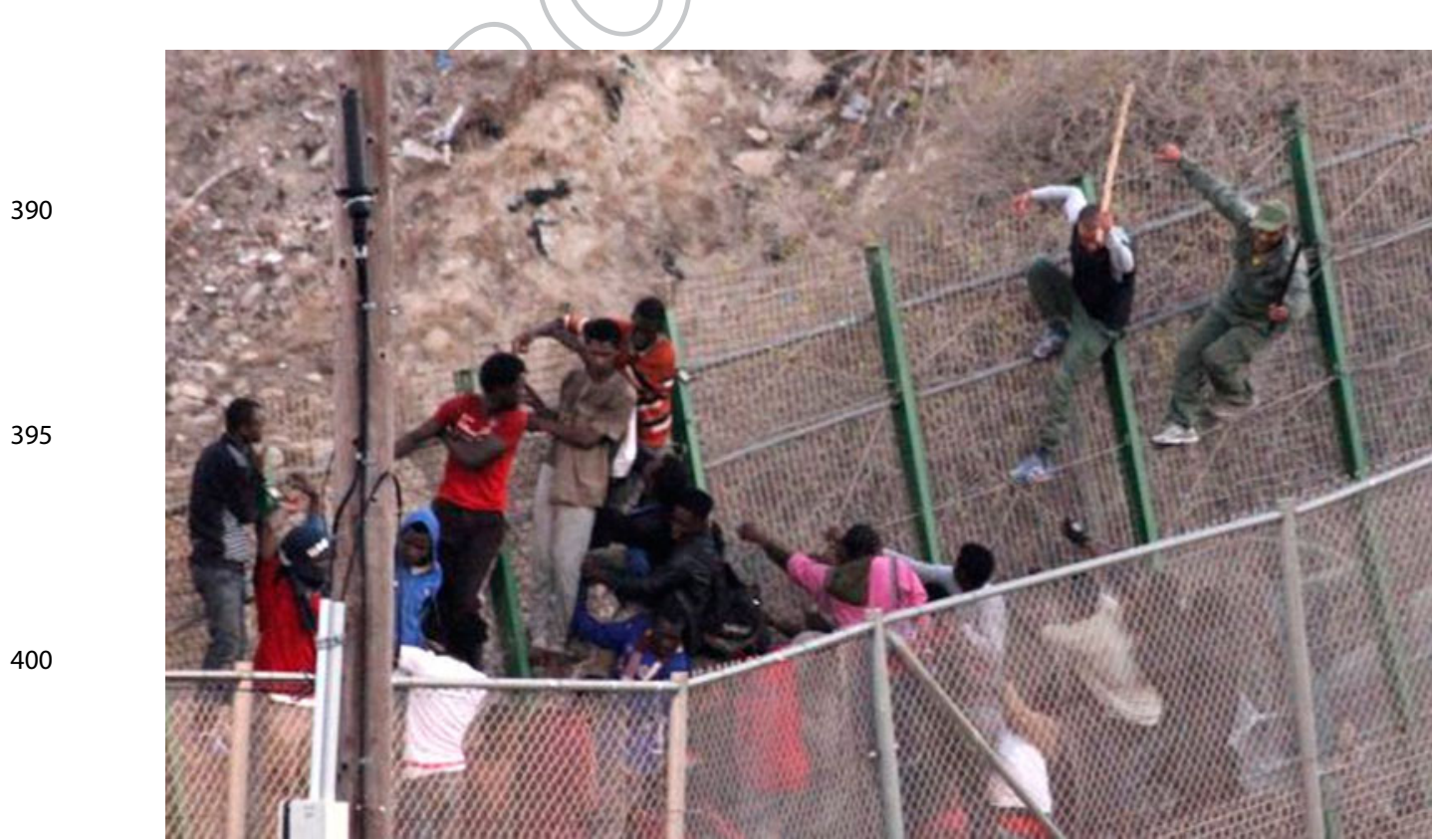

Figure 3. A la derecha, agentes marroquíes bajan de la valla a palos a subsaharianos./ ANTONIO RUIZ (On the right, Moroccan officers get sub-Saharans off the fence, beating them back./ ANTONIO RUIZ). 


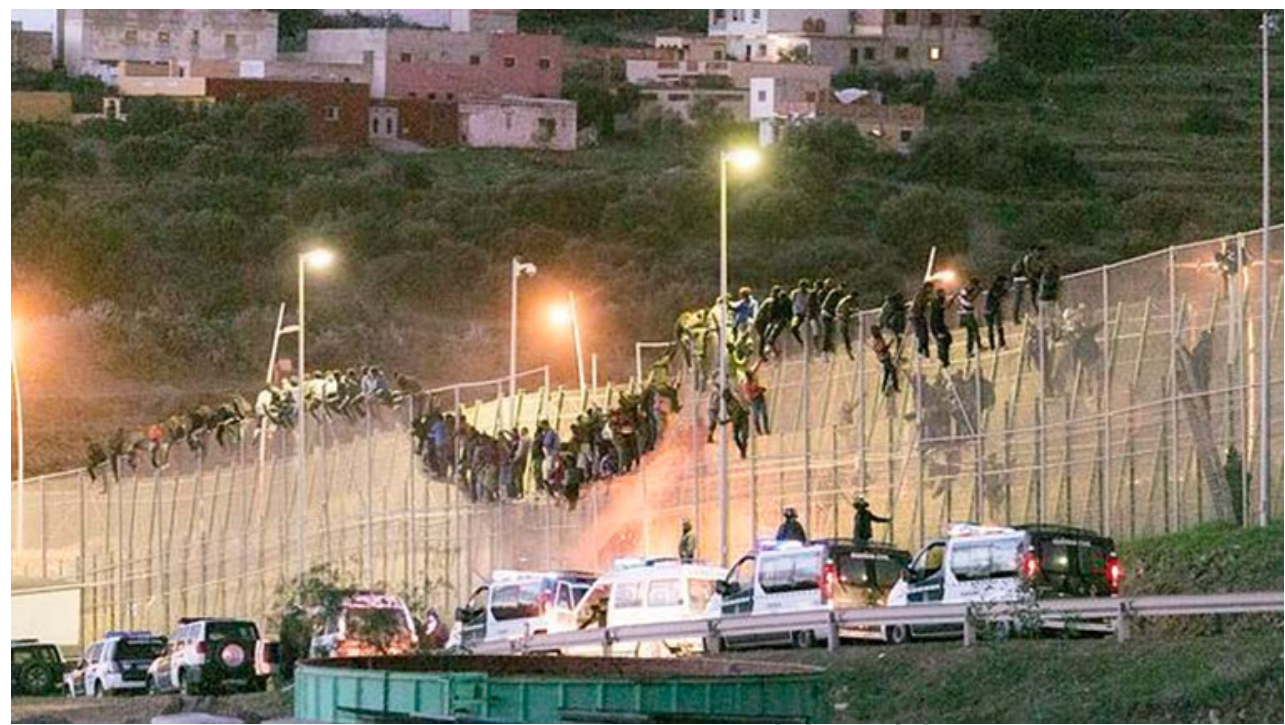

Figure 4. EFE. Los inmigrantes encaramados a la valla esta madrugada (The immigrants climbing the fence at dawn).

\section{TEXT 3}

150 inmigrantes, atrapados entre las vallas de Melilla tras un salto masivo (150 immigrants, trapped between the fences of Melilla after a massive assault).

Las mallas antitrepa impiden a los subsaharianos atravesar la segunda reja del triple vallado (The mesh prevents the sub-Saharans from going through the second grille of the third fence).

El País, Agencias, 18-06-2014.

http://politica.elpais.com/politica/2014/06/18/actualidad/1403073688_458046.html (Figure 3)

http://www.abc.es/espana/20141015/abci-inmigrantes-melilla-valla-201410150803. html

Unos 200 inmigrantes intentan saltar la valla de Melilla por segunda vez en 24 horas (Some 200 immigrants try to jump the fence in Melilla for the second time in 24 hours).

La mitad de los subsaharianos ha quedado en la zona intermedia entre las dos alambradas fronterizas (Half of the sub-Saharans have been kept in the intermediate area between the two border wire fences).

$A B C, 15-10-2014$ (Figure 4).

\subsection{Portraying the challenge of risking one's life in order to fight for a dream: representation of sub-Saharans jumping the fence in Melilla}

One of the main characteristics of the texts analysed is that immigrants are represented as a group. In van Leeuwen's terms $(2008,38)$, they are collectivized and assimilated, and therefore their identity as individuals is avoided; they are never represented individually (Wodak 2008, 37). What matters for the Spanish people is that the immigrants arrive in 
large groups and seem to be invading the country. In this sense, the idea of indetermination is present, because immigrants are represented as unspecified, anonymous individuals (Van Leeuwen 2008, 39). Therefore, the general tendency in the corpus is the homogenization of immigrants instead of their differentiation. This homogenization implies that their life stories as individuals are not important.

Sub-Saharan immigrants are represented as invasive and uncontrollable. Showing them carrying two sticks in text 3 suggests that they are violent agents because they use force and fight against the social security forces in order to jump the fence. They are portrayed as active human beings: they are the protagonists in the process of jumping, which implies that they accept the challenge of risking their life in order to fight to get to Europe and have an opportunity to settle there. For example, in text 1 agency and power are strong characteristics of the immigrants represented because they appear sitting on the fence, implying that they were able to jump over it. They are now closer to being in Spain, which gives them power. The fact that there are two immigrants on a post, and at a higher level than the other immigrants are, contributes to their representation as empowered because they stand out visually. Moreover, these immigrants are active in the process of leaving their countries of origin and deciding to risk their lives by jumping the fence at Melilla. This is clear in all the texts under analysis, but text 4 is noteworthy because we can see the process of their going from one side of the fence to the other. Jumping the fence implies a change in their lives because immigrants consider that their efforts, sacrifices and risks have been worth it: they are on the other side of the fence.

Immigrants are portrayed as active social actors responsible for their success or failure in the migratory process. The fact that they are portrayed as jumping without permission highlights the idea of illegality, of coming to Spain without official documents that would allow them to stay and work in the country. The idea of illegality is also highlighted when the Spanish social security forces appear, as in texts 2 and 4 . The line of cars next to the fence in text 4 reinforces the necessity of stopping immigrants from jumping the fence and creates a second symbolic fence in the middle ground.

In this text, the line of cars from the Civil Guards (Guardia Civil) and the Civil Guards whose job is to try to stop immigrants from jumping the fence shows the division between two worlds: that of immigrants without documents and that of Spaniards as citizens with recognized rights. In this way, immigrants are portrayed as non-citizens who try to land in Spain illegally; they do not have the legal or political status that citizens have, following Anderson $(2013,94)$ :

Citizenship designates a legal relation between an individual and a state: a person must be granted entry to the territory of the state of which he is a citizen and he cannot be deported from that state. Citizenship also indicates a political relation: a citizen is a stakeholder, or has a membership in the political community delineated by the (nation) state. In this way citizenship fuses the legal and the political.

They are also portrayed as desperate and strategic in that they wait near the fence or just sit on it (see the group of immigrants on the fence in texts 1 and 4). They wait to have a chance to jump, trying to avoid being stopped by security forces. In this sense they are both passive (Van Leeuwen 2008, 32), just waiting to jump, and are potential invaders (active) at the same time. Moreover, their action of invading implies that they have to be rescued, so the active-passive dichotomy goes together again (see 
immigrants in the process of jumping in texts 2, 3 and 4). When they are captured, it is the members of the social security forces who are active. The immigrants assume a passive role because they need help and protection. However, they are active when they succeed in climbing the fence that divides Melilla from Morocco (see texts 1 and 4). In these texts, the police and the Civil Guards are shown attempting to stop immigrants from jumping the fence. This portrayal indicates their active role in not allowing immigrants to enter Spain.

Generally, immigrants are represented as passive victims when they are not successful in immigrating, because they are stopped from jumping the fence or because they need help and protection from the Spanish people after their arrival. They are portrayed as active when they start immigrating and when they are able to jump the fence, thus being close to their dream of entering Spain.

Following Van Leeuwen's (2008) visual representation of social actors allows us to observe the main strategies of distancing and the type of interaction constructed in the images. Firstly, the images analysed construct a distance between the people represented and the audience. The images are shot from a distance, which is impersonal because immigrants appear backgrounded (see texts 1 and 4). This angle of portrayal contributes to depicting the reality of immigrants as very far from Spanish society. This figurative distance highlights the distant situation between immigrants' reality and the autochthonous population. Moreover, they are seen from the back and therefore do not interact with the audience (see text 2). They are also covered up by the fence (see text 3 ). These characteristics contribute to their dysphemistic representation (see Section 4.1).

Secondly, regarding social relations, we observed the general tendency to represent immigrants at eye level (see texts 1, 2, 3 and 4) taking into consideration the vertical angle. In addition, we see immigrants from the front in texts 1 and 2 and from the side in texts 3 and 4. Following Van Leeuwen $(2008,139)$, the angles are useful to observe power and involvement between the represented immigrants and the audience. In this sense, it is noteworthy that, although readers have power, not looking at immigrants from above (due to the angles chosen) does not contribute to giving readers more symbolic power. However, there are differences in involvement: in texts 1 and 2, looking at immigrants from the front is a way of confronting them, whereas by looking at them from the side in texts 3 and 4 readers are more detached from the immigrants' actions. This is especially clear in text 3: the fence that appears foregrounded that covers some of the immigrants does not favour a relation between the social actors represented and the audience.

Thirdly, we consider social interaction important in order to observe if the social actors look at the readers. The four images under analysis make clear that there is no direct interaction between the depicted immigrants and the audience. Consequently, readers are not invited to identify, to cooperate or sympathize with these immigrants. Moreover, the immigrants do not look directly at the reader, so the reader is not invited to be involved in the action. A crucial point in social interaction is whether the represented people look at the viewer or not. As stated, none of the participants looks at readers, and consequently they are represented as objects, following Van Leeuwen $(2008,141)$ : “[ ... ] the strategy of objectification, representing people as objects for our scrutiny, rather than as subjects addressing the viewer with their gaze and symbolically engaging with the viewer in this 
way". These texts are examples of images in which the social actors represented do not request direct involvement with the audience.

\section{Discussion}

The analysis presented in the previous section points out that the press conveys the idea that the arrival of sub-Saharan immigrants is a social problem. The journalists who create the news items belong to the majority group. They are elite individuals working for the media, and as symbolic elite they have power to transmit ideology and even racist attitudes (van Dijk 2007, 26). Normally, it is not a priority to transmit a positive image of immigrants or to examine the reasons why they go to Spain. On the contrary, the analysis shows that what is highlighted is the idea that immigrants invade Spain and are a threat to the main group.

Immigrants are represented as wild individuals who, by any means, want to enter Spain, and this justifies the use of violence. In this sense, immigrants are portrayed as invaders who are very difficult to control. This makes the main group worried and scared about the immigrants' arrival and possible presence in Spanish society. In this way the wethey, citizens-foreigners dichotomy is perpetuated, and it is confirmed that the coexistence of citizens and non-citizens has become a permanent feature in contemporary society. This is clearly observed in texts 2 and 4 . The representation of members of the Spanish security forces highlights the idea of two very different realities: that of immigrants trying to enter Spain and that of the Civil Guards doing their job of stopping them from arriving.

In this sense, the news items analysed can be considered examples of racist discourse in society. Movies, textbooks, everyday conversations, news reports, among others are inside elite racism (van Dijk 2006, 34). This discursive racism used by the elites comprises much more than simply ideas or words, so that the only means to combat it is through consistent and critical discourses from different groups of the population, including those that belong to the main white group (van Dijk 2006, 30).

News items normally reinforce the dominant hegemonic discourse of the intrusive and invasive arrival of immigrants, highlighting that they are "problem people", whose arrival is a burden for Spanish society. The texts analysed support the rhetoric of immigrants arriving illegally, in groups, with nothing to offer and as invaders. This highlights their representation as "the others", excluded from the main group, which contributes to the invisibility of their human rights by presenting them apart from the main group. Moreover, there is no reference to social justice that promotes universal acceptance, because immigrants are portrayed as arriving intrusively and therefore as non-citizens, with no access to the rights that the main group has. Their illegal entry contributes to their marginalization and discrimination, and consequently they are deprived of exercising their rights. The news items analysed make clear that immigrants' human rights are not taken into consideration when they are portrayed as entering Spain by jumping the fence in Melilla. The lack of undocumented migrants' access to rights, their deportation or detention, can be perceived as violating their human rights (Anderson 2013, 137). In fact, CDA is very useful for studying the ideology behind each linguistic and visual choice when narrating linguistically or visually the immigrants jumping the said fence. 
The negative representation of immigrants does not support the portrayal of immigrants' human rights. That would involve foregrounding social strategies of integration in the visuals such as: their representation with people from the main group of Spanish society who are not the police or the Civil Guards, their portrayal working or doing any other normal activity such as shopping or playing sports, or their depiction as arriving in legal ways, among others.

Presenting immigrants in a negative way favours discrimination towards them and highlights the invisibility of human rights by pointing out that their entry is illegal. Consequently, justice has to be done in order to protect the local population but not immigrants and their integrity and dignity as human beings. In this sense it is necessary for the press to vindicate human rights for immigrants instead of simply portraying them as invaders.

The news items about sub-Saharans could contribute to highlighting the importance of justice and promoting a culture of peace instead of creating fear in the audience. This could be achieved if the news items examined the reality of immigrants in their countries of origin: readers would be conscious of their needs and of the importance of promoting justice so that their situation could improve and human rights could be respected in their countries and in the country of arrival.

The texts analysed in this article are good examples of connecting immigrants with problems by the recurrent reference to their illegal entry and of ignoring human rights by their invisibility. Consequently, this article is a vindication for the discourse of human rights to be present in the press elites' discourse in order to contribute to increasing readers' social awareness of the difficult social situation of sub-Saharans and the necessity of reclaiming the respecting of human rights.

Immigrants are represented as excluded and different from the Spanish people. The creation of a fence is a physical barrier that symbolizes the division of two worlds: that of the main group and that of the minority, in this case sub-Saharan immigrants. The fence, in fact, reinforces the dichotomy of we-they, citizens-non-citizens, autochthonous population and foreigners, whites and non-whites. As Richardson and Wodak $(2013,247)$ put it: "The construction of in- and out groups necessarily implies the use of strategies of self-representation and the negative representation of others".

The fact that there are news items on the importance of reinforcing the fence in order to stop the arrival of immigrants makes clear that this is a priority for the government (see for example text 3, where immigrants can be observed between both fences) instead of foregrounding the importance of human rights. Reinforcing the fence seems to be more important than developing policies and international laws that facilitate immigrants' integration and protect human beings. The creation and reinforcement of fences is the main measure taken by the government. There are no agreements with the immigrants' countries of origin to ensure they arrive safely. Consequently, African governments do not assume the responsibility of regularizing the arrival of immigrants to Europe.

\section{Conclusions}

The news items analysed show that the press does not normally give information about why sub-Saharan immigrants arrive and does not make reference to what happens to these immigrants after they first arrive. In other words, the information offered by the press is basic and incomplete. It does not favour understanding the circumstances that 
make immigrants decide to start a new life in Europe. The general tendency is to highlight the problematization of immigration and to concentrate on the first moment of arrival. The portrayal of immigrants jumping the fence in an aggressive way is an effective way of doing this.

The fact that the news items analysed highlight that immigrants try to enter Spain in an uncontrollable way does not help us understand the reasons why they leave their countries of origin and their social situation there. Presenting immigrants as invaders suggests that they are problematic people that are a burden for Spain from the very first moment of arrival. Consequently, immigrants are perceived in a negative way, as people with no documents and therefore non-citizens who invade us.

The news items are created by journalists who are part of mainstream society; therefore, they have power and their voices are legitimated. The press offers what the general public expects to read but also helps construct that expectation. In this sense, the we-they dichotomy is highlighted by publishing negative news articles about immigrants and portraying their arrival as an invasion, in order to create fear in the Spanish population.

There are no references to human rights in the texts analysed. This means that immigrants' human rights are not taken into consideration, and their invisibility suggests that they are deprived of them. In this sense, it is necessary to mention that the press has power to point out situations in which immigrants are deprived of human rights. Consequently, the press also has power to portray the difficulties that immigrants experience and to demand that human rights be respected and their social situation improved. This article intends to be a contribution to foreground some biases in the media and the way they are accomplished through visual displays.

\section{Disclosure statement}

No potential conflict of interest was reported by the author.

\section{Notes on contributor}

María Martínez Lirola is Professor of the Department of English at the University of Alicante, Spain and Research Fellow at the University of South Africa (UNISA). Her main areas of research are Critical Discourse Analysis, Systemic Functional Linguistics and Applied Linguistics. She has published more than 80 papers and seven books, such as Main Processes of Thematization and Postponement in English (Peter Lang, 2009). She has been a visiting scholar in different universities such as: University of British Columbia (Vancouver, Canada 2014), Carleton University (Ottawa, Canada, 2012), University of South Africa, UNISA (Pretoria, South Africa, 2012), University of Anahuac Mayad (Mérida, Mexico, 2008), University of Kwazulu-Natal (Pietermaritzburg, South Africa, 2006) and Macquarie University (Sydney, Australia, 2005). She has presented papers in international congresses all over the world.

\section{References}

$A B C$. (January 1, 2012-January 1, 2015). http://www.abc.es.

Alonso Belmonte, Isabel, Anne McCabe, and Daniel Chornet-Roses. 2010. "In Their Own Words: The Construction of the Image of Immigrant in Peninsular Spanish Broadsheets and Freesheets." Discourse and Communication 4 (3): 227-242.

Anderson, Bridget. 2013. Us and Them? The Dangerous Politics of Immigration Control. Oxford: Oxford University Press. 
Arango, Joaquín. 2002. La fisonomía de la inmigración en España. El campo de las ciencias y las artes, 139 («El nuevo orden demográfico»). Madrid: Servicio de Estudios BBVA.

Bacon, David. 2008. Illegal People: How Globalization Creates Migration and Criminalizes Immigrants. Boston, MA: Beacon Press.

Bañón, Antonio M. 2002. Discurso e inmigración. Propuestas para el análisis de un debate social. Murcia: Universidad de Murcia.

Bañón, Antonio M., and Javier Fornielles, eds. 2008. Manual sobre comunicación e inmigración. San Sebastián: Gakoa.

Bañón, Antonio M., and Samantha R. Romero. 2013. "Ánimo. Estamos con vosotros: Messages of Solidarity Written in a Visitors' Book During a Sit-in Conducted by a Group of Immigrants in Spain." Discourse \& Society 24 (1): 3-26.

Checa y Olmos, Francisco, ed. 2008. La inmigración sale a la calle. Comunicación y discursos políticos sobre el discurso migratorio. Barcelona: Icaria.

Collins, Jock. 2007. "Immigrants as Victims of Crime and Criminal Justice Discourse in Australia." International Review of Victimology 14: 57-79.

Concepción Sepúlveda, Luis Gilberto, Miquel Rodrigo Alsina, and Pilar Medina Bravo. 2008. “Niveles semánticos de las representaciones sociales de la inmigración subsahariana. Los sucesos de Ceuta y Melilla según ABC." Estudios sobre el Mensaje Periodístico 14: 129-48.

Crespo, Eliecer, and María Martínez Lirola. 2012. "Lexical and Visual Choices in the Representation of Immigration in Spanish Press." Spanish in Context 9 (1): 27-57.

Dauvergne, Catherine. 2008. Making People Illegal: What Globalization Means for Migration and Law. Cambridge: Cambridge University Press.

Dembour, Marie-Bénédicte, and Tobias Kelly, eds. 2011. Are Human Rights for Migrants? Critical Reflections on the Status of Irregular Migrants in Europe and the United States. London: Routledge. van Dijk, Teun A. 2006. "Discurso de las élites y racismo institucional." In Medios de comunicación e inmigración, edited by Manuel Lario Bastida, 16-34. Murcia: Convivir sin Racismo: CAM - Obra Social.

van Dijk, Teun A. 2007. "Racismo y discurso en América Latina: una introducción." In Racismo y discurso en América Latina, edited by Teun A. van Dijk, 21-34. Barcelona: Gedisa.

van Dijk, Teun A. 2008. "Reproducir el racismo: el rol de la prensa." In La inmigración sale a la calle. Comunicación y discursos políticos sobre el discurso migratorio, edited by Francisco Checa y Olmos, 19-49. Barcelona: Icaria.

van Dijk, Teun A., ed. 2011. Discourse Studies. A Multidisciplinary Introduction. 2nd ed. London: Routledge.

705 El País. (January 1, 2012-January 1, 2015). http://www.elpais.es.

Estévez, Ariadna. 2012. Human Rights, Migration, and Social Conflict: Toward a Decolonized Global Justice. New York: Palgrave Macmillan.

Fairclough, Norman, Jane Mulderrig, and Ruth Wodak. 2011. "Critical Discourse Analysis." In Discourse Studies. A Multidisciplinary Introduction, edited by Teun A. Van Dijk, 2nd ed., 357-378. London: Routledge.

$710 \quad$ Fairclough, Norman, and Ruth Wodak. 1997. "Critical Discourse Analysis." In Discourse as Social Interaction. Discourse Studies: A Multidisciplinary Introduction. Vol. 2, edited by Teun A. Van Dijk, 258-284. London: Sage.

Gavison, Ruth. 2010. "Immigration and the Human Rights Discourse: The Universality of Human Rights and the Relevance of States and of Numbers." Israel Law Review 43 (1): 7-48.

Gee, James Paul. 2014. An Introduction to Discourse Analysis. Theory and Method. 4th ed. London: Routledge.

Goh, Bee Chen, Baden Offord, and Rob Garbutt, eds. 2012. Activating Human Rights and Peace. Theories, Practices and Context. Surrey: Ashgate.

Goodhart, Michael. 2009. Human Rights: Politics and Practice. Oxford: Oxford University Press.

Goodhart, Michael, and Anja Mihr, eds. 2011. Human Rights in the 21st Century. Continuity and Change since 9/11. New York: Palgrave Macmillan.

Gready, Paul, and Wonter Vanhenhole. 2014. "What Are We Trying to Change? Theories of Change in Development and Human Rights." In Human Rights and Development in the New Millennium. 
Towards a Theory of Change, edited by Paul Gready and Wonter Vanhenhole, 1-26. London: Routledge.

Hanson, Gordon H. 2009. The Economics and Policy of Illegal Immigration in the United States. Washington, DC: Migration Policy Institute.

Hatoss, Anikó. 2012. "Where Are You From? Identity Construction and Experiences of 'Othering' in the Narratives of Sudanese Refugee-Background Australians." Discourse \& Society 23 (1): 47-68.

Human Rights Declaration. 1948. Resolution 217 A (III), December 10.

Kaced, Assia. 2011. "The Illegal Immigrant: Victim/Hero. An Analytical Study on Content of Two Algerian Daily Newspapers: El Chourouk (Arabic) and El Watan (French)." In Media, Migration and Public Opinion: Myths, Prejudices and the Challenge of Attaining Mutual Understanding Between Europe and North Africa, edited by Iván Ureta, 93-109. Bern: Peter Lang.

KhosraviNik, Majid. 2010. "The Representation of Refugees, Asylum Seekers and Immigrants in the British Newspapers: A Critical Discourse Analysis." Journal of Language and Politics 9 (3): 1-28.

Kiwan, Nadia. 2009. Identities, Discourses and Experiences. Young People of North African Origin in France. Manchester: Manchester University Press.

Kress, Gunther, and Theo van Leeuwen. 2006. Reading Images: The Grammar of Visual Design. 2nd ed. London: Routledge Press.

Lario Bastida, Manuel, ed. 2006. Medios de comunicación e inmigración. Murcia: Convivir sin Racismo: CAM - Obra Social.

Marchetti, Raffaele, and Nathalie Tocci, eds. 2011. Civil Society, Conflicts and the Politicization of Human Rights. Tokyo: United Nations University Press.

Markovitz, Jonathan. 2011. Racial Spectacles. Explorations in Media, Race, and Justice. London: Routledge.

740 Martínez Lirola, María. 2006. "A Critical Analysis of the Image of Immigrants in Multimodal Texts." Linguistics and the Human Sciences 2 (3): 377-397.

Martínez Lirola, María, ed. 2008. Inmigración, discurso y medios de comunicación. Alicante: Instituto Alicantino de Cultura Juan Gil Albert.

Martínez Lirola, María, ed. 2010. Migraciones, discursos e ideologías en una sociedad globalizada. Claves para su mejor comprensión. Alicante: Instituto Alicantino de Cultura Juan Gil Albert.

Martínez Lirola, María, ed. 2013. Discourses of Immigration in Times of Economic Crisis: A Critical Perspective. Newcastle upon Tyne: Cambridge Scholars.

Martínez Lirola, María. 2014. "Approaching the Representation of Sub-Saharan Immigrants in a Sample from the Spanish Press: Deconstructing Stereotypes." Critical Discourse Studies 11 (4): 482-499.

750 Mestre Chust, José Vicente. 2007. La necesidad de la educación en derechos humanos. Barcelona: Editorial UOC.

Moore, Kerry, Bernhard Gross, and Terry Threadgold, eds. 2012. Migrations and the Media. New York: Peter Lang.

Mullor, Mónica. 2011. Inmigrantes subsaharianos. Una aproximación a las claves de la exclusión. Madrid: Asociación Círculo Africano y ONGD África Activa.

Newton, Lina. 2008. Illegal, Alien, or Immigrant: The Politics of Immigration Reform. New York: New York University Press.

Osler, Audrey, and Hugh Starkey. 2010. Teachers and Human Rights Education. London: Trentham Books.

Pham, T. Thao. 2014. Moroccan Immigrant Women in Spain. Honor and Marriage. New York: Lexington Books.

Riccio, Bruno. 2001. "Following the Senegalese Migratory Path Through Media Representation." In Media and Migration. Constructions of Mobility and Difference, edited by Russell King and Nancy Wook, 110-126. London: Routledge.

Richardson, John, and Ruth Wodak. 2013. "The Impact of Visual Racism: Visual Arguments in Political Leaflets of Austrian and British Far-Right Parties." In Critical Discourse Analysis. Vol. IV. Applications, Interdisciplinary Perspectives and New Trends, edited by Ruth Wodak, 245-274. London: Sage.

Risse, Thomas, Stephen C. Ropp, and Kathryn Sikkink. 2013. The Persistent Power of Human Rights: From Commitment to Compliance. Cambridge: Cambridge University Press. 
Rodríguez Breijo, Vanessa. 2010. “La representación televisiva de los inmigrantes africanos: invisibilidad, desconocimiento y precariedad." Revista Mediterránea de Comunicación 1: 113-140.

Rubio-Marín, Ruth. 2014. Human Rights and Immigration. Oxford: Oxford University Press.

Sobrados León, Maritza. 2011. "La inmigración como problema. Percepciones sociales y representaciones mediáticas." Prisma Social 6: 1-26.

Spener, David. 2009. Clandestine Crossings: Migrants and Coyotes on the Texas-Mexico Border. Ithaca, NY: Cornell University Press.

Steiner, Henry J., Philip Alston, and Ryan Goodman. 2007. International Human Rights in Context: Law, Politics, Morals. 3rd ed. Oxford: Oxford University Press.

Thym, Daniel. 2008. "Respect for Private and Family Life Under Article 8 ECHR in Immigration Cases: A Human Right to Regularize Illegal Stay?" International and Comparative Law Quarterly 57: 87-112.

Triandafyllidou, Anna, and Thanos Maroukis. 2012. Migrant Smuggling. Irregular Migration from Asia and Africa to Europe. London: Macmillan.

Ureta, Iván, ed. 2011. Media, Migration and Public Opinion: Myths, Prejudices and the Challenge of Attaining Mutual Understanding Between Europe and North Africa. Bern: Peter Lang.

Van Leeuwen, Theo. 2000. "Visual Racism." In The Semiotics of Racism. Approaches in Critical Discourse Analysis, edited by Michael Reisigl and Ruth Wodak, 333-350. Wien: Passagen Verlag.

Van Leeuwen, Theo. 2008. Discourse and Practice. New Tools for Critical Discourse Analysis. Oxford: Oxford University Press.

Wodak, Ruth. 2011. "Critical Linguistics and Critical Discourse Analysis." In Discursive Pragmatics, edited by Jan Zienkowski, Jan-Ola Östman, and Jef Verschueren, 50-70. Amsterdam: John Benjamins.

Wodak, Ruth, and Michael Meyer. 2009. "Critical Discourse Analysis: History, Agenda, Theory and Methodology." In Methods of Critical Discourse Analysis, edited by Ruth Wodak and Michael Meyer, 2nd ed., 1-33. London: Sage. 